\title{
The Effect of Orthographic Knowledge on Word Identification and Reading Comprehension of Iranian EFL Learners
}

\author{
Masoud Khalili Sabet \\ English Department, University of Guilan, Rasht, Guilan, Iran \\ E-mail: sabetma2002@yahoo.com \\ Omid Ostad (Corresponding author) \\ English Department, University of Guilan, Rasht, Guilan, Iran \\ E-mail: omidostad007@gmail.com
}

$\begin{array}{lll}\text { Received: 13-12-2015 } & \text { Accepted: 16-02-2016 } & \text { Advance Access Published: March 2016 } \\ \text { Published: 01-05-2016 } & \text { doi:10.7575/aiac.ijalel.v.5n.3p.152 } & \text { URL: http://dx.doi.org/10.7575/aiac.ijalel.v.5n.3p.152 }\end{array}$

\begin{abstract}
The present study attempts to employ orthographic knowledge enhancement as a tool in order to determine its efficiency in improving Iranian EFL learners' reading comprehension. Orthographic knowledge can be defined as one's familiarity with the general spelling rules of a language, or the ability to defer those letter combinations that are permissible form those that are not, which makes it an exceptional requirement for effective word identification and as a result successful reading comprehension skill. In doing so, 55 male and female students learning English at preintermediate level in a language institute in Astaneh, Guilan, Iran were randomly selected and were equally divided into an experimental and a control group. A researcher-made reading comprehension test followed by multiple-choice items as well as a word identification measure was given to both groups as a pre-test, and then the experimental group received the treatment in eighteen 30-minute sessions, in which the instructor taught skills to enhance students' orthographic knowledge. Meanwhile, the control group did not receive any specific treatment. Finally the post-test, which was the same as the pre-test was administered. Their scores were calculated through computer softwares. The results indicated that raising orthographic knowledge results in significant improvement in both word identification and reading comprehension. The findings of this study can benefit EFL learners in improving their reading comprehension skill.
\end{abstract}

Keywords: Orthographic knowledge, Word Identification, Reading comprehension, Iranian EFL Learners

\section{Introduction}

In EFL/ESL situations, according to Ostad \& Tarang (2015), reading is arguably the most emphasised skill; since it usually occupies the most class time for a variety of purposes. Without possessing the required reading proficiency, second language learners may not perform as expected in developing reading skills required for communication. Orthographic knowledge, which is an important factor to reading development, is defined by Perfetti (1984, p.47) as 'the knowledge a reader has about permissible letter patterns'. Another more elaborated definition was given by Vellutino et al (1994) which defined orthographic knowledge as 'the ability to represent the unique array of letters that define a printed word, as well as the general attributes of the writing system such as segmentation dependencies, structural redundancies, and letter position frequencies' (p. 314).

As put forth by scholars, orthographic knowledge can be of two main kinds: general orthographic knowledge, and word-specific orthographic knowledge (Hagiliassis et al., 2006; Vellutino et al., 1994). Word-specific orthographic knowledge is defined as the knowledge of letter sequence of individual words which works with the assistance of the memory. As an example of how word-specific orthographic knowledge works, one should have the knowledge to distinguish between 'take' and 'make' as real words and 'teik' and 'meik' as not real ones.

General orthographic knowledge is defined as being familiar with the general spelling rules governing the whole writing system. It is the ability to distinguish permissible sub-lexical clusters from non-permissible ones. As an example, general orthographic knowledge allows one to judge 'pake' as a more likely legitimate word since its spelling is based on a permissible sequence of letters (like take, and make) in the writing system of English.

Lexical Quality Hypothesis states that establishing well-specified lexical representations give rise to automaticity (Perfetti, 1992; Perfetti \& Hart, 2002). According to Ehri (2005), exposure to and experience with written words assist strong and detailed orthographic representations in memory. 'Moving away from decoding words through letter-sound correspondence and towards recognising them quickly and automatically is an important factor underlying efficient reading' (Castles \& Nation, 2008, p. 1). 
Despite the large number of EFL speakers, around 750 million people, little research in reading has been done for this expanding population as compared to conducted research with ESL and native ESL speakers, approximately 375 million people each, Graddol (1997). To improve the students' reading skills, schools in EFL contexts have to work harder since they are deprived of an English-speaking environment, as a result, schools tend to employ more effective methods of teaching reading. Although there is still dispute on the process behind learning to read, word identification is a major component in reading comprehension which is one of the important areas of research underlying reading comprehension (Fukkink, Hulstin, \& Simis, 2005). Words are the building blocks of language which either serve as a unit bearing meaning or fulfil a grammatical role.

There is no doubt that quick, accurate, and correct retrieval of words from the mental lexicon lies at the heart of a successful reading. The idea that word recognition is one of the key elements of reading comprehension of native speakers, EFL and ESL learners is very well supported by research ( Ehri, 2005; Koda, 2005).

Very little attention has been paid to the impact of skills underlying word identification which is the principal element in successful reading comprehension. Whether students rely on orthographic knowledge for word identification is still a question. This study tries to investigate the effect of word-specific orthographic knowledge on the reading comprehension skill of Iranian EFL learners. The effect of word-specific orthographic knowledge on word identification as well as reading comprehension will be examined since as Goodman (2006) pointed out, the objective of reading is to comprehend the written material.

One of the major barriers to the learning of English in Iran is the limited exposure outside the language classrooms, and the absence of an environment in which learners can use the language for communication. This exposure to spoken language can also help the learners to have a strong vocabulary base which is a key requirement for successful reading (Saville-Toike, 1984). Considering all the efforts done in Iran to improve the reading comprehension of Iranian students, they still lack the word identification skill and vocabulary knowledge for reading comprehension.

Another problem is the difference between Persian and English alphabet and their linguistic systems. English employs a Roman alphabet, which is written from left to right, while Persian uses the Arabic alphabet for writing and reading which is written from right to left and that could add to the difficulty level of learning English for Persian learners.

\subsection{Significance of the study}

To successfully understand a text, word identification has to be employed, which in turn is supported by orthographic knowledge (Juel, Griffith, \& Gough, 1986; Perfetti, 1985). This has given rise to a great bulk of research on the reading of English native speakers and ESL students (Geva, 2006; Grabe, 2004; Jean \& Geva, 2009; Koda, 2005, 2007).

Studies on EFL can be more beneficial and more to the point, according to Koda (2007), if they are conducted on the junior high school or high school students since in most studies young children have been targeted. Therefore, in this study, Iranian junior and senior high school students have been investigated.

Iranian students have not fully acquired the skills needed for word recognition and reading comprehension as compared to native speakers of English. By investigating this trait in Iranian learners, remedial programmes and new strategies for teaching could be introduced to help improve these students' reading ability.

\subsection{Research Questions and Hypotheses}

The following question is the major issue of the present study to be explored:

Does raising orthographic knowledge affect the word identification and reading comprehension of Iranian preintermediate EFL students?

The following hypothesis is proposed based on the above-mentioned research question:

$\mathrm{H}_{0}$ : Raising orthographic knowledge does not have any effects on the word identification and reading comprehension of Iranian pre-intermediate EFL learners.

\section{Review of the literature}

\subsection{Theoretical background}

English has a segmental nature and an alphabetic writing system. Although, when decoding the segments, phonological awareness is activated and graphemes are converted into phonemes (Adams, 1990), simply employing this graphemephoneme conversion is not enough for a successful identification of written words. This is partially due to the fact that English has a deep orthography, in which there are usually low levels of correspondence between speech sounds and written symbols. In fact, while it is true that phonological awareness does assist orthographic learning, it is not the only factor responsible for the difficulty of the development of orthographic knowledge. This is partly because there is not a one-to-one sound-letter correspondence in almost $80 \%$ of English words (Shankweiler \& Fowler, 2004). It means that a single phoneme may be represented in several written forms and a grapheme can have different pronunciations. Therefore, letter-sound correspondence is the only way for word identification and reading which makes word identification easily confusing since pronunciations cannot always guarantee spelling prediction.

The case of recognising exception words is an intriguing one, since orthographic knowledge plays a great role in exception words recognition tasks. The more the students' difficulty in exception words recognition, the poorer their underlying orthographic skills (Ricketts, Nation, \& Bishop 2007). In order to avoid a misidentification of words based 
on grapheme-phoneme conversion rules, students need to familiarise their oral vocabulary with an exception word (Ricketts et al., 2007; Share, 1995). In such cases, orthographic knowledge proves its important contribution in the identification of irregular words (Harm \& Seidenberg, 1999; Manis, Seidenberg, Doi, McBride-Change, \& Petersen, 1996; Roman, Kirby, Parilla, Wade-Wooley, and Deacon, 2009). Hagiliassis et al. (2006) proposed that exception words could, to some extent, be decoded, however, in most cases exception words have to be fully spelled to be recognised.

For homophones recognition, the role of orthographic knowledge substantially increases while phonological awareness plays a small role (Scholes, 1998). Homophones are words with identical pronunciation, but with different orthographic representations, such as 'to', 'two', and 'too'. Since these words have the same pronunciation, employing a phonological strategy does not differentiate them leaving one with no choice than to know the specific order of the letters defining the word whose meaning is to be assessed accurately.

Hagiliassis et al (2006) investigated to see if orthographical processing operates independently of the phonological processing. In the study, 117 native speakers (grades 3 to 5 elementary school) were tested, with homophone verification task as the central measure of orthographic knowledge. It was shown that this task could measure word recognition variance with minimum phonological awareness intrusion. As a result, orthographic knowledge was the only key to successfully completing this task.

While it is true that phonological awareness development is crucial to nonsense words or regular but unfamiliar words, reading comprehension and exception word reading need more than sound-letter mapping (Manis et al., 1996; Nation \& Snowling, 2004; Harm \& Seidenberg, 1999). Phonological strategies may not be much of assistance when reading tasks focus on evaluating an individual's comprehension of a written text rather than pronunciation (Stanovich et al., 1991; Juel et al., 1986; Stanovich, 1992).

\subsection{Empirical background}

In spite of what was discussed earlier, previous empirical research suggests that the predictive power of orthographic knowledge by far dominates that of phonological awareness in reading comprehension (Stanovich \& West 1989; Wagner \& Barker, 1994; Barker, Torgesen, \& Wagner, 1992; Cunningham \& Stanovich, 1993; Juel et al., 1986). According to Cunningham et al. (2001) orthographic knowledge is found to be predictive of development of word identification. In their study, the participants were 39 students in lower-class elementary school ranging from grade one to three. Six tests for word recognition and orthographic processing were administered as phonological tasks to subjects when they ranged from grades 1 to 3 . After controlling the influence of phonological awareness the orthographic processing skill test in second-graders had different variance $(16.3 \%)$ in their word recognition abilities when they became third-graders.

Roman et al. (2009) selected 92 participants, Canadian students in grades 4, 6, and 8, in their study to determine the unique role of the big four variables underlying reading development. The variables included morphological awareness and naming speed which were investigated alongside phonological awareness and orthographic knowledge. The participants had to read real words and nonsense words. As most studies investigate students merely at early elementary and elementary school years, this study was important since its participants' age had a broader range. The results showed that orthographic knowledge functions more independently as a contributing factor to real word reading, and also as the most crucial predictor in real word reading in the mentioned three grades. The data revealed that participants of the study relied more on orthographic knowledge in reading real words. The researchers justified the results by pointing out to the fact that older learners were acquiring more irregular vocabulary items, making strong orthographic knowledge a determining factor for the word identification skill. In addition, in nonsense word reading, orthographic knowledge had an unequalled role. It was only in pseudo-words reading aloud that the power of orthographic knowledge decreased. The researchers contended that pseudo-words cannot be distinguished by sight, therefore, students were forced to rely more on their phonological awareness.

\section{Methodology}

\subsection{Participants}

The participants in the present study were 55 (31 female and 24 male) students that were learning English as a foreign language at pre-intermediate level in Zabansara Language institute in Astaneh, Guilan. Their ages ranged from 12 to 16 with a mean of 14.5. To select the right participants, the Oxford Placement Test (OPT) version 2 was administered in a group session to a total number of 90 students both male and female. 60 students were selected, and were randomly divided into an experimental group including 30 learners and a control group including the same number as well. However, two students from the control group did not attend the post-test session and were left out of the study, therefore making the control group to shrink to 28 by the end of the study. Also, in the experimental group, one student dropped out in the middle of the project, one was reportedly ill for almost half of the treatment sessions, and on the post-test session, the answer sheet of one more student was lost accidentally. All were left out of the study; as a result the experimental group was accounted for as having 27 participants.

\subsection{Instruments and materials}

In order to gather the required data in the present study the following instruments were used:

The Oxford placement Test: OPT version 2 was administered to ensure the homogeneity of the participants. OPT is a renowned multiple choice item placement test, having 60 questions in grammar, reading, and vocabulary with one point 
for each correct item. The time allocated was 30 minutes. Only those students whose scores fell in the range of B1, according to the manual, were selected to match the characteristics of pre- or lower-intermediate.

Reading comprehension test: it was designed by Mehrpour et al. (2012) and was used as the pretest and posttest for both groups. The test contains 6 relatively short passages that ranged from 115 to 150 words and each passage was followed by 5 multiple choice items, with a total of 30 items. The average index of reliability was 0.70 . Also, the reliability of the test was calculated via KR-21 which was 0.76 revealing that the measure was indeed a reliable instrument of reading comprehension ability. To show the concurrent validity of the test, the authors had also administered the reading comprehension part of the TOEFL to the participants. They indicated that the scores of the TOEFL reading test and the present reading comprehension test correlated with the index of 0.68 which stands for the acceptable concurrent validity.

DIBELS: in the present study they were used as the word identification measures. DIBELS are a renowned group of standardised tests which are mostly used in early literacy and reading development. Each of these tests has been proved to have a high degree of reliability. The three subtests used were phoneme segmentation (reliability=.97), nonsense word fluency (reliability=.94), and first sound fluency (reliability=.86). 20 items from the phoneme segmentation, 20 from the first sound fluency and 10 from the nonsense word fluency were selected to from a 50 -item test.

Orthographic knowledge raising sessions: they were used as the treatment lasting for 18 sessions, two sessions a week, 30 minutes each session (a total of 540 minutes) throughout the summer term in Zabansara Language Centre. What the instructors did in these sessions were attempts to improve the learners' ability to recognise the permissible orthographic patterns of the target words independent of phonology. Trying to increase the learners' knowledge of word spelling, the instructors would for example teach the learners to differentiate between the correct spelling of words (e.g. game) and the incorrect or pseudo-correct ones (geim*), by putting the rhyming words in clusters and encouraging learners to find the common patterns in them (e.g. tame, came, name, dame, same, lame, etc.). Also, students were trained to know where and when to double the consonants in verbs and nouns, the spelling of irregular form of the verbs versus regular ones, the matter of silent letters and their combinations (e.g. drought), exceptions to spelling rules, plural markers and irregular plural words and their spellings, and when to leave out the final letter when suffixes are added.

\section{Results}

\subsection{Data Analysis}

Table 1 displays the pre-test results of the word identification test for both groups. The mean of the control group was 29.18 and the experimental group obtained a mean of 29.19 , with the standard deviation of control and experimental group being 5.221 and 4.583 respectively. However, regarding the fact that the $p$-value $(p=0.997)$ is more than alpha $(\alpha=0.05)$, as shown in table 2 , one could conclude that there is no statistically significant difference between the means of the two groups.

Table 1. Pre-test of Word Identification Test

\begin{tabular}{llccccccc}
\hline & & & & \multicolumn{2}{c}{$95 \%$ Confidence Interval for Mean } \\
& $\mathrm{N}$ & Mean & Std. Deviation & Std. Error & Lower Bound & Upper Bound & Minimum & Maximum \\
\hline control & 28 & 29.18 & 5.221 & .987 & 27.15 & 31.20 & 21 & 38 \\
Exp. & 27 & 29.19 & 4.583 & .882 & 27.37 & 31.00 & 21 & 38 \\
Total & 55 & 29.15 & 4.667 & .503 & 28.15 & 30.15 & 21 & 38 \\
\hline
\end{tabular}

Table 2. ANOVA of word identification pre-test

\begin{tabular}{cccccc}
\hline & Sum of Squares & df & Mean Square & F & Sig. \\
\hline Between Groups & .144 & 2 & .072 & .003 & .997 \\
Within Groups & 1850.891 & 53 & 22.300 & & \\
Total & 1851.035 & 55 & & & \\
\hline
\end{tabular}

In Table 3, the pre-test results of the reading comprehension of the two groups are shown. In the pre-test results of the reading comprehension test, the control group obtained the mean of 13.04 and the standard deviation of 2.546 . The experimental group had the mean of 13.11 and the standard deviation of 2.708. Again, with the p-value of the test being 0.989 (see table 4) which is more than $\alpha(0.05)$, meaning there is no significant difference between the means of the two groups. 
IJALEL 5(3):152-160, 2016

156

Table 3. Reading Comprehension Pre-test

\begin{tabular}{ccccccccc}
\hline & & & & \multicolumn{3}{c}{$95 \%$ Confidence Interval for Mean } \\
& $\mathrm{N}$ & Mean & Std. Deviation & Std. Error & Lower Bound & Upper Bound & Minimum & Maximum \\
\hline control & 28 & 13.04 & 2.546 & .481 & 12.05 & 14.02 & 9 & 18 \\
Exp. & 27 & 13.11 & 2.708 & .521 & 12.04 & 14.18 & 9 & 18 \\
Total & 55 & 13.09 & 2.551 & .275 & 12.55 & 13.64 & 9 & 18 \\
\hline
\end{tabular}

Table 4. ANOVA of Reading Comprehension Pretest

\begin{tabular}{cccccc}
\hline & Sum of Squares & df & Mean Square & F & Sig. \\
\hline Between Groups & .141 & 2 & .070 & .011 & .989 \\
Within Groups & 553.115 & 53 & 6.664 & & \\
Total & 553.256 & 55 & & & \\
\hline
\end{tabular}

After the treatment sessions for the experimental group were carried out the post-test for both control and experimental groups was administered with the results discussed below. In order to see if the instructions have, in fact, been effective or not the paired t-test for pre and post tests of both groups in both tasks was calculated.

Table 5. T-test statistics for pre and post test of word identification of control group

\begin{tabular}{|c|c|c|c|c|c|}
\hline & & Mean & $\mathrm{N}$ & Std. Deviation & Std. Error Mean \\
\hline \multirow[t]{2}{*}{ Pair 1} & $\begin{array}{l}\text { Pre-test of control } \\
\text { group word } \\
\text { identification }\end{array}$ & 29.18 & 28 & 5.221 & .987 \\
\hline & $\begin{array}{l}\text { Post-test of control } \\
\text { group word } \\
\text { identification }\end{array}$ & 29.50 & 28 & 4.918 & .929 \\
\hline
\end{tabular}

Table 6. Paired Sample Tests

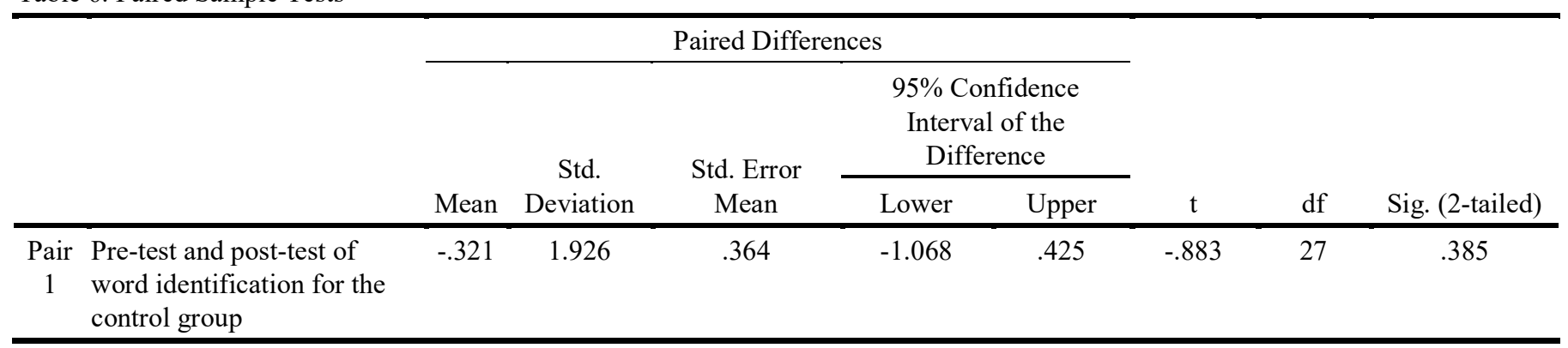

What is resulted as the output of paired t-test for control group (Tables 5 and 6) shows that the difference between the two means of pre $(M=29.18)$ and post $(M=29.50)$ test is not statistically significant. The p-value $(0.385)$ is more than the set $\alpha(0.05)$.

Table 7. Paired Samples Statistics for reading

\begin{tabular}{llllll}
\hline & Mean & $\mathrm{N}$ & Std. Deviation & Std. Error Mean \\
\hline Pair 1 & $\begin{array}{l}\text { Pre-test of the control } \\
\text { group }\end{array}$ & 13.04 & 28 & 2.546 & .481 \\
& $\begin{array}{l}\text { Post-test of the control } \\
\text { group }\end{array}$ & 13.14 & 28 & 2.549 & .482 \\
\hline
\end{tabular}




\begin{tabular}{|c|c|c|c|c|c|c|c|c|}
\hline & \multicolumn{5}{|c|}{ Paired Differences } & \multirow[b]{3}{*}{$\mathrm{t}$} & \multirow[b]{3}{*}{$\mathrm{df}$} & \multirow{3}{*}{$\begin{array}{l}\text { Sig. }(2 \\
\text { tailed })\end{array}$} \\
\hline & \multirow[b]{2}{*}{ Mean } & \multirow[b]{2}{*}{ Std. Deviation } & \multirow{2}{*}{$\begin{array}{l}\text { Std. Error } \\
\text { Mean }\end{array}$} & \multicolumn{2}{|c|}{$\begin{array}{c}95 \% \text { Confidence Interval } \\
\text { of the Difference }\end{array}$} & & & \\
\hline & & & & Lower & Upper & & & \\
\hline $\begin{array}{l}\text { Pair } 1 \text { pre-test and post- } \\
\text { test of reading } \\
\text { comprehension for } \\
\text { the control group }\end{array}$ & -.107 & .916 & .173 & -.463 & .248 & -.619 & 27 & .541 \\
\hline
\end{tabular}

As indicated by tables 7 and 8, the differences in the statistical traits of the two tests, i.e. pre-test and post-test of the control group in reading comprehension test is not statistically significant. This is because the observed level of significance $(\mathrm{P}$-value $=.541)$ is more than the pre-determined level of significance $(\alpha=0.05)$. Therefore the control group results had not made any significant progress.

Table 9. Paired t-test of experimental group

\begin{tabular}{clcccc}
\hline & Mean & N & Std. Deviation & Std. Error Mean \\
\hline Pair 1 & $\begin{array}{l}\text { Pre-test of word } \\
\text { identification orthographic } \\
\text { group }\end{array}$ & 29.19 & 27 & 4.583 & .882 \\
$\quad \begin{array}{l}\text { Post-test of word } \\
\text { identification orthographic } \\
\text { group }\end{array}$ & 34.00 & 27 & 4.938 & .950 \\
\hline
\end{tabular}

Table 10. Paired Samples Test for word identification of experimental group

\begin{tabular}{|c|c|c|c|c|c|c|c|c|}
\hline & \multicolumn{5}{|c|}{ Paired Differences } & \multirow[b]{3}{*}{$\mathrm{t}$} & \multirow[b]{3}{*}{$\mathrm{df}$} & \multirow[b]{3}{*}{ Sig. (2-tailed) } \\
\hline & \multirow[b]{2}{*}{ Mean } & \multirow{2}{*}{$\begin{array}{c}\text { Std. } \\
\text { Deviation }\end{array}$} & \multirow{2}{*}{$\begin{array}{l}\text { Std. Error } \\
\text { Mean }\end{array}$} & \multicolumn{2}{|c|}{$\begin{array}{l}95 \% \text { Confidence } \\
\text { Interval of the } \\
\text { Difference }\end{array}$} & & & \\
\hline & & & & Lower & Upper & & & \\
\hline $\begin{array}{l}\text { Pair Pre- and posts test of word } \\
1 \text { identification for the } \\
\text { orthographic group }\end{array}$ & -4.815 & 1.618 & .311 & -5.455 & -4.175 & -15.462 & 26 & .000 \\
\hline
\end{tabular}

The results in tables 9 and 10 are the evidence that the instruction has been effective. As displayed by Table 9 , the difference between the pre-test and post-test of the experimental group is significant $(\alpha=0.05, \mathrm{P}=.000)$. This means participants had a higher score in post-test $(M=34, S D=4.938)$, after being instructed in order to raise their orthographic knowledge.

Table 11. The t-test for pre and post test of experimental group in reading

\begin{tabular}{clcccc}
\hline & Mean & N & Std. Deviation & Std. Error Mean \\
\hline Pair 1 & $\begin{array}{l}\text { Pre-test of reading } \\
\text { comprehension orthographic } \\
\text { group }\end{array}$ & 13.11 & 27 & 2.708 & .521 \\
& $\begin{array}{l}\text { Post-test of reading } \\
\text { comprehension orthographic } \\
\text { group }\end{array}$ & 17.30 & 27 & 3.291 & .633 \\
\hline
\end{tabular}




\begin{tabular}{|c|c|c|c|c|c|c|c|c|}
\hline & \multicolumn{5}{|c|}{ Paired Differences } & \multirow[b]{3}{*}{$\mathrm{t}$} & \multirow[b]{3}{*}{$\mathrm{df}$} & \multirow[b]{3}{*}{ Sig. (2-tailed) } \\
\hline & \multirow[b]{2}{*}{ Mean } & \multirow{2}{*}{$\begin{array}{c}\text { Std. } \\
\text { Deviation }\end{array}$} & \multirow{2}{*}{$\begin{array}{l}\text { Std. Error } \\
\text { Mean }\end{array}$} & \multicolumn{2}{|c|}{$\begin{array}{l}95 \% \text { Confidence Interval of } \\
\text { the Difference }\end{array}$} & & & \\
\hline & & & & Lower & Upper & & & \\
\hline $\begin{aligned} \text { Pair } 1 & \text { Pre- and post-test of } \\
& \text { orthographic group in } \\
& \text { reading comprehension }\end{aligned}$ & -4.185 & 1.331 & .256 & -4.712 & -3.659 & -16.336 & 26 & .000 \\
\hline
\end{tabular}

As displayed in Tables 11 and 12, in reading comprehension in post-test section $(M=17.30, S D=3.291)$ the experimental group had a better performance than the one prior to the instruction $(\mathrm{M}=13.11, \mathrm{SD}=2.708)$ considering that the $\mathrm{p}$-value was less than $\alpha(\alpha=0.05, \mathrm{p}=.000)$.

Table 13. the correlation of word identification and reading comprehension

\begin{tabular}{cccc}
\hline & & $\begin{array}{c}\text { Post-test of } \\
\text { word } \\
\text { identification }\end{array}$ & $\begin{array}{c}\text { Post-test of reading } \\
\text { comprehension }\end{array}$ \\
\hline $\begin{array}{c}\text { Post-test word } \\
\text { identification }\end{array}$ & $\begin{array}{c}\text { Pearson Correlation } \\
\text { Sig. (2-tailed) }\end{array}$ & 1 & .681 \\
$\mathrm{~N}$ & 55 & .005 \\
\hline Post-test reading & Pearson Correlation & .681 & 55 \\
comprehension & Sig. (2-tailed) & .005 & 1 \\
& $\mathrm{~N}$ & 55 & 55 \\
\hline
\end{tabular}

The correlation coefficient of the word identification test and the reading comprehension test has been calculated (0.681). This means that there is a significant relationship between the two variables. With the observed level of significance being 0.005 (which is lower than the set significance level $\alpha=0.05$ ). These facts indicate that the relationship between word identification and reading comprehension is a strong one, and that improvement in word identification can result in an improved reading comprehension.

\section{Discussion}

Turning back to the discussion in the literature, not many studies have tried to investigate the effect of raising orthographic knowledge on reading comprehension of Iranian EFL learners. This study has tried to fill the gap in this particular field of knowledge. Apart from studying reading comprehension, word identification was also included in the present study.

Regarding all the above mentioned issues and discussions, we turn to the question guiding this study:

Does raising orthographic knowledge affect the word identification and reading comprehension of Iranian EFL students?

As displayed by Table 9, the difference between the pre-test and post-test of word identification the experimental group is significant $(\alpha=0.05$; $p$-value $=.000)$. This can be interpreted as the improvement in the participants' score in posttest $(\mathrm{M}=34.00, \mathrm{SD}=4.938)$, after being instructed in order to raise their phonological awareness than before the instructions and receiving the treatment which was $(M=29.19, \mathrm{SD}=4.583)$. Regarding the reading comprehension, the experimental group progress was observed (pre-test $\mathrm{M}=13.11, \mathrm{SD}=2.708$; Post-test $\mathrm{M}=17.30, \mathrm{SD}=3.291$ ), considering the fact that the difference between the two groups is a statistically significant one $(\alpha=0.05$, sig. $=.000)$. This rejects the null hypothesis that raising orthographic knowledge does not have any effects on the word identification and reading comprehension of Iranian EFL learners. In other words, orthographic knowledge can improve the word identification of Iranian EFL learners and in turn their reading comprehension.

The findings of this study are in line with that of Cunningham's et al. (2001). In which orthographic knowledge was found to be predictive of development of word identification as the participants grew older. The results indicated that orthographic knowledge raising tasks can benefit the EFL learners and positively improve their word identification and, to a lesser degree reading comprehension. It was asserted that orthographic knowledge is a key factor in the development of word identification and in turn reading comprehension. Therefore, the greater the mastery of spelling and orthographic rules, the better the word identification and the more refined the reading comprehension skill which is the extraction of the meaning from the passage. Also, Roman et al. (2009) have proved that there is a close relationship between the orthographic knowledge and word identification. If one manages to establish a strong basis in orthographic knowledge accompanied by automatic word identification, one can save one's own cognitive resources which are required for higher order processes of comprehending. 
6. Conclusion, pedagogical implications, and future studies

The findings of the present study contain crucial pedagogical implications for classroom practice and educational systems and their policies. It was concluded that If orthographic knowledge of Iranian students is raised it can help them so as to enhance their word identification skill and reading comprehension ability. All these observations have been helpful to Iranian participants of the study.

It is worth mentioning that word identification tasks mostly deal with the accuracy of pronunciation with little, if not any, regards for meaning. This is while the primary goal of reading comprehension is far more than merely correct pronunciation of single words (Scholes, 1998). Comprehending the information presented in a text and understanding it is a much more important goal (Goodman, 2006). While it is true that meaning can be extracted through decoding, this method is described as an exhaustive and boring one. Also, relying on a letter-by-letter decoding method is not fruitful or productive, if not counter-productive, since one's cognitive resources are being split into two parts, one for extracting the meaning, and the other for constructing pronunciations of single words. When the ultimate goal of reading is comprehension, it is crucial to be able to get the meaning form the text as rapidly and automatically as possible.

It can be inferred from the results that a good command of orthographic knowledge provides a good solution to speed up the written information processing. Learners can easily identify individual words in texts (via letter strings comprising them) provided that they have mastery over orthographic knowledge. This awareness of the formal features of the words permits the straight mapping of the orthographical features to semantic ones with no assist from phonological awareness. This automatic link, connecting form to meaning without the interference of the sound is crucial to those EFL learners who lag behind in phonological awareness.

Classroom practices for orthographic knowledge raising can include encouraging the employment of full cues in reading by learners, visualising words and their syllables they are comprised of, instruction of spelling rules, and formal spelling instruction, considering the fact that many orthographic deficiencies are the result of lack of formal training, or little attention being paid to the matter. Structured and regular spelling sessions are of utmost importance, which are recommended to be based on sound-letter correspondence, to include phonemic segmentation, and to have the potential to increase the learners' sensitivity to orthographic syllable structure of individual words, making them able to break down words.

The results of the t-test, ANOVA, and other statistical procedures confirmed the essential role of orthographic knowledge in word identification and reading comprehension, however, questions arise as to how much, and if any, of the precious class time should or could be allocated to improve orthographic knowledge. The researchers hereby call for more research of experimental nature to investigate if students can gain more form spelling and orthographic interventions than merely reading skills.

The present study investigated a group of participants who were Iranian EFL learners at the pre-intermediate level. The results could have been more generalisable if greater variety of participants with different L1 backgrounds had been available, or if the study were to be carried out with a larger sample and more instruction time allotment.

\section{Acknowledgements}

The authors wish to thank Mr Sajad Bahmanyar, the director of Zabansara Language Institute for his cooperation and support throughout the whole project.

\section{References}

Adams, M. J. (1990). Beginning to read: Thinking and learning about print. Cambridge: MIT Press.

Castles, A., \& Nation, K. (2008). Learning to be a good orthographic reader. Journal of Research in

Reading, 31(1), 1-7.

Cunningham, A.E., \& Stanovich, K.E. (1993). Children's literacy environments and early word recognition subskills. Reading and Writing: An Interdisciplinary Journal, 5(2), 193-204.

Cunningham, A. E., Perry, K. E., \& Stanovich, K. E. (2001). Converging evidence for the concept of orthographic processing. Reading and Writing: An Interdisciplinary Journal, 14(5), 549-568.

Ehri, L.C. (2005). Learning to read words: Theory, findings, and issues. Scientific Studies of Reading, 9(2), $167-188$.

Fukkink, R. G., Hulstin, J., Simis, A. (2005). Does training in second-language word recognition skills affect reading comprehension? Modern Language Journal, 89(1), 54-75.

Geva, E. (2006). Second-language oral proficiency and second-language literacy. In D. August \& T. Shanahan (Eds.), Developing literacy in second-language learners: Report of the National Literacy Panel on Language - Minority Children and Youth (pp.123-139). Mahwah, NJ: Erlbaum.

Goodman, K. S. (2006). A critical review of DIBELS. In K. S. Goodman (Ed.), The truth about DIBELS: What it is, what it does (pp. 1-39). Portsmouth, NH: Heinemann.

Grabe, W. (2004). Research on teaching reading. Annual Review of Applied Linguistics, 24, 44-69. 
Graddol, D. (1997). The future of English? A guide to forecasting the popularity of the English language in the 21 st century. London: British Council.

Hagiliassis, N., Pratt, C., \& Johnston, M. (2006). Orthographic and phonological processes in reading. Reading and Writing, 19(3), 235-263.

Harm, M., \& Seidenberg, M.S. (1999). Reading acquisition, phonology, and dyslexia: Insights from a connectionist model. Psychological Review, 106(3), 491-528.

Jean, M., \& Geva, E. (2009). The development of vocabulary in English as a second language children and its role in predicting word recognition ability. Applied Psycholinguistics, 30(1), 153-185.

Juel C., Griffith P. L., \& Gough P. B. (1986). Acquisition of literacy: A longitudinal study of children in first and second grade. Journal of Educational Psychology, 78(4), 243-255.

Koda, K. (2005). Insights into Second Language Reading: A Cross-linguistic Approach.NY: Cambridge University Press.

Koda, K. (2007). Reading and language learning: Crosslinguistic constraints on second language reading development. Language Learning, 57(Supplement 1), 1-44.

Nation, K., \& Snowling, M. J. (2004). Beyond phonological skills: Broader language skills contribute to the development of reading. Journal of Research in Reading, 27(4),342-356.

Manis, F.R., Seidenberg, M., Doi, L.M., McBride-Chang, C., \& Petersen, A. (1996). On the bases of two subtypes of developmental dyslexia. Cognition, 58(2), 157-195.

Mehrpour, S., Safighi, F., \& Bagheri, Z. (2012) Teaching Reading Comprehension Strategies to Iranian EFL PreUniversity Students. The Journal of Teaching Language Skill. 66/4, 108-139

Ostad, O., \& Tarang, M. (2015). The effect of schematic knowledge on Iranian EFL learners' reading comprehension. International Journal of Applied Linguistics \& English Literature. 4(6):154-159

Perfetti, C.A. (1984). Reading ability. In R. Sternberg (Ed.), Human abilities: An information processing approach (pp. 59-81). New York: W. H. Freeman and Co.

Perfetti, C. A. (1985). Reading Ability. New York: Oxford University Press.

Perfetti, C.A. (1992). The representation problem in reading acquisition. In P. Gough, L. Ehri \& R. Treiman (Eds.), Reading acquisition (pp. 145-174). Hillsdale, NJ: Erlbaum.

Perfetti, C.A., \& Hart, L. (2002). The lexical quality hypothesis. In L. Vehoeven. C. Elbro, \& P. Reitsma (Eds.), Precursors of functional literacy (pp. 189-213). Amsterdam/Philadelphia: John Benjamins.

Ricketts, J., Nation, K., \& Bishop, D. V. M. (2007). Vocabulary is important for some, but not all reading skills. Scientific Studies of Reading, 11(3), 235-257.

Roman, A., Kirby, J., Parilla, R., Wade-Woolley, L., \& Deacon, S. H. (2009). Towards a comprehensive view of the skills involved in word reading in Grades 4, 6, and 8. Journal of Experimental Child Psychology. 102(1), 96-113.

Saville-Troike, M. (1984). What really matters in second language learning for academic achievement? TESOL Quarterly, 18(2), 199-219.

Scholes, R. J. (1998). The case against phonemic awareness. Journal of Research in Reading, 21(3), 177-188.

Shankweiler, D., \& Fowler, A. E. (2004). Questions people ask about the role of phonological processes in learning to read. Reading and Writing: An Interdisciplinary Journal, 17(5), 483-515.

Share, D.L. (1995). Phonological recoding and self-teaching: Sine qua non of reading acquisition. Cognition, 55(2), $151-218$.

Stanovich, K.E., \& West, R.F. (1989). Exposure to print and orthographic processing. Reading Research Quarterly, 24(4): 402-433.

Stanovich, K. E., West, R. F., \& Cunningham, A. E. (1991). Beyond phonological processes: Print exposure and orthographic processing. In S. Brady \& D. Shankweiler (Eds.), Phonological processes in literacy (pp. 219-235). Hillsdale, NJ: Lawrence Erlbaum.

Stanovich, K. E. (1992). Speculations on the causes and consequences of individual differences in early reading acquisition. In P. B. Gough, L. C. Ehri, \& R. Treiman (Eds.), Reading acquisition (pp. 307-342). Hillsdale, NJ: Lawrence Erlbaum Associates.

Vellutino, F. R., Scanlon, D. M., \& Tanzman, M. S. (1994). Components of reading ability: Issues and problems in operationalizing word identification, phonological coding, and orthographic coding. In G.R. Lyon (Ed.), Frames of reference for the assessment of learning disabilities: New views on measurement issues (pp. 279-329). Baltimore, MD: Paul 